\title{
Fishing tactics dynamics of a Mediterranean small-scale coastal fishery
}

\author{
Francesc Maynou ${ }^{\mathrm{a}}$, Laura Recasens and Antoni Lombarte \\ Institut de Ciències del Mar (CSIC), Psg Marítim de la Barceloneta, 37-49 08003 Barcelona, Spain
}

Received 21 December 2010; Accepted 30 May 2011

\begin{abstract}
We analyzed the small-scale fishery in the port of Vilanova i la Geltrú (NW Mediterranean) to assess the fishing practices in this fishery and produce economic indicators of its status. We defined the fishing tactics (or métiers) of this fishery with a multivariate analysis approach for evaluating the main fishery resources and fishing gears employed. Our results show that netters in this fishery practice 7 types of fishing tactics. Five of these fishing tactics, in terms of target species, gear and seasonality, are also used in other small-scale Mediterranean fisheries. The main types of fishing gear (trammel nets, gillnets) and target species (Sepia officinalis, Solea vulgaris, Mullus surmuletus and Merluccius merluccius), and a well defined seasonality, are also observed in other studies of Mediterranean small-scale fisheries. We show that the seasonal rotation of fishing tactics is determined by the availability of different fish species rather than market price. Identifying the fishing tactics, which in the Mediterranean are relatively limited in number, of small-scale fisheries provides information for developing monitoring and management strategies for these fisheries. We also assessed the economic performance of the small-scale fishery in Vilanova i la Geltrú and its conflicts with other uses of the coastal zone. We conclude that small-scale fisheries are an economically viable activity although seriously threatened by concurrent uses of the coastal zone (conflict with other extractive activities; competition for space with tourism and leisure activities; pollution). The integrated management of the uses of the coastal zone is necessary in order to sustain small-scale fisheries, which have become less important in economic terms, but which are an important social component of local coastal communities and are a source of high quality seafood with a low ecological impact.
\end{abstract}

Key words: Small-scale fishery / Multivariate analysis / Fishing tactics / Métiers / Trammel net / Gillnet / Northwestern Mediterranean

\section{Introduction}

Small-scale fisheries were the main users of marine living resources on the Mediterranean coast for many centuries; however, since the second half of the 20th century they have become a marginal and hardly sustainable economic activity in most Mediterranean countries. The growth of semiindustrial fleets (trawl and purse-seine fishing, Lleonart 2008) and the intensification of other economic uses of the coastal zone (tourism and aquaculture, among others) have relegated small-scale fishing to a position in which it has to compete for resources and space with many other activities (both extractive and non-extractive) (Colloca et al. 2004; Griffiths et al. 2007). Its importance in terms of catches and economic value has decreased greatly, especially in EU countries of the northern Mediterranean. This has brought with it the corresponding loss of many social and cultural aspects of the coastal communities. However, at the same time the demand for highquality fresh fish has increased (Griffiths et al. 2007) and consumers are beginning to demand sea products obtained with

\footnotetext{
a Corresponding author: maynouf@icm.csic.es
}

environmentally friendly fishing gears. To stem the loss in competitiveness of small-scale fisheries and to guarantee the sustainable exploitation of the coastal zone, it is necessary to understand the dynamics of this type of fishery, and identify the factors that contribute to its decline in order to determine appropriate measures for conserving this activity for the future (Guyader 2007).

Although the general picture is that these fisheries are undergoing a serious crisis in Europe (Guyader 2007) and elsewhere (Alió et al. 2000) due to conflict or competition with other users of coastal living resources (both professional fishing fleets and recreational fishers) and limited economic profit, there are few studies on European small-scale coastal fisheries (Griffiths et al. 2007; Guyader 2007). In the Mediterranean, small-scale fisheries still represent $80 \%$ of the vessels of the EU Mediterranean fleet, and provide around 100000 jobs (C.O.M. 2002). Recent studies describing the fishing gear and seasonal activity of the small-scale fleet show that static gear (mainly lnets and to a lesser extent gillnets and longlines) are the basis of the coastal small-scale fisheries practiced in the Mediterranean (Alarcón 2001; Colloca et al. 2004; 
Forcada et al. 2010; García-Rodríguez et al. 2006; Merino et al. 2008; Tzanatos et al. 2006) and elsewhere in southern European waters (Stergiou et al. 2006). The seasonal variability and the spatial heterogeneity of the coastal zone promote the diversification of fishing practices in the form of fishing tactics or métiers (Forcada et al. 2006; Merino et al. 2008; Tzanatos et al. 2006).

Mediterranean small-scale fisheries are referred to in the literature as multispecies and multifleet, or mixed, fisheries (Alarcón 2001; Colloca et al. 2004; Tzanatos et al. 2006). In such fisheries, the vessels in a given fleet segment may carry out different fishing practices depending on the skipper, the market conditions or tradition, so that the target species changes throughout the year. For a given target species the gear used and the fishing location may also change following the seasonal dynamics of the resource (Tzanatos et al. 2006). Therefore, each fishing practice impacts exploited species differently, which makes it difficult to accurately assess the relationship between the fishing effort applied by the fleet and the fishing mortality exerted on the target species. Hence, ignoring the behaviour of the fleet can give an incomplete picture of the dynamics of the fishery and lead to erroneous stock assessments (Salas and Gaertner 2004).

Before each fishing operation or fishing trip, the skipper must choose the fishing location, gear to use and target species. To make this decision, the skipper usually takes into account the season of the year (which is an indicator of target species availability), weather and market prices (Salas and Gaertner 2004). Following Pelletier and Ferraris (2000) and Laloë and Samba (1991) we term these combinations fishing tactics, although other names, such as métiers (Biseau and Gondeaux 1988) or fishing strategies (He et al. 1997) can also be found in the literature. In practice, the number of fishing tactics that can be practiced by a boat in a small-scale fleet segment is constrained by the technological possibilities of a small boat (generally 6 to $14 \mathrm{~m}$ in length), the possibilities of investing in different gear types (boasts usually have a maximum of 2 or 3 main gear types plus a few secondary ones), the knowledge or tradition of the skipper, and in some cases the fishing gears that are legal in an area. As in other Spanish Mediterranean fisheries, management is based only on input control, which basically limits the effective working time (maximum $12 \mathrm{~h} /$ day, 5 days/week) and establishes the technical aspects of the fishing gear (maximum number of net pieces or pots, mesh size of nets, number of hooks in longlines).

Identifying fishing tactics consists in determining the main types of fishing operations, i.e. constructing groups of fishing operations that correspond to similar choices in terms of target species, gear, season and fishing location. Here we follow the multivariate approach of Pelletier and Ferraris (2000) to classify the catch profiles obtained from commercial catch/effort data. We complemented this classification with ancillary variables (such as month and the technical characteristics of the vessel) and interview data.

The objectives of this paper were to describe the main fishing tactics in a representative fishing port (Vilanova i la Geltrú) of the western Mediterranean and their evolution over the last 10 years, as well as assess the current economic situation of this fleet segment.

\section{Materials and methods}

\subsection{Data sources}

We obtained the daily catch data of the small-scale fleet for the period from 1 Jan. 2000 to 31 Dec. 2009 (10 complete years) for the port of Vilanova i la Geltrú (henceforth, Vilanova for short) from the Fishermen's Association of Vilanova (Fig. 1A). Vilanova was chosen because it is representative of a Catalan port with an active small-scale coastal fleet. It ranked 3rd in terms of catches (out of 20 commercial fishing ports in Catalonia) during the 10 year study period. In 2009, this small-scale coastal fleet landed $230 \mathrm{t}$ of fin fish, crustaceans and molluscs with a total ex-vessel value of 1.6 M€.

As in other Mediterranean fisheries, the boats in this fleet undertake daily fishing trips of 6 to $12 \mathrm{~h}$, and return to their homeport to sell the catch. It is obligatory for fishers to sell their catch through the fish auction of the Fishermen's Association. According to our personal interviews with the fishers, the small-scale fleet segment sells $>90 \%$ of the catch through this channel (unlike semi-industrial fleet segments, for which there are other commercial channels), and the rest is used for personal consumption. In the Mediterranean the catches of smallscale fisheries can be equated with the landings because there are hardly any discards, except for damaged specimens that cannot be sold. The fleet comprises 53 units (in 2008, technical characteristics, Table 1) and lands 131 species (or commercial categories) of marine fish, crustaceans and molluscs. The complete data set comprises 274077 records reporting the catch $(\mathrm{kg})$ and price $(€ / \mathrm{kg})$ of each species sold at the Vilanova fish auction by each boat on each day during the 2000-2009 study period. Unfortunately, it is not possible with these data to analyse the concurrent use of more than one fishing gear per fishing trip, as practiced by numerous Mediterranean smallscale fisheries (cf. Forcada et al. 2010); such an analysis is only possible with on board monitoring of the fishing activity or if fishers fill out log-books correctly and in detail.

Vessels in the small-scale fleet segment in Vilanova are issued 3 types of fishing license: rastell or "beam trawl" targeting purple-dye murex (Bolinus brandaris), bivalve dredges and netters. The first two groups have fishing tactics that are clearly determined by their main fishing gear and target species. Here, we focus on the third group (netters), which in Vilanova comprised 21 vessels using a wide variety of nets and secondary fishing gear (such as longlines and traps), and who follow different fishing tactics at different times of the year (Table 1). The boats in the segment of small-scale netters are on average larger than the boats in the other two segments (Table 1). In 2009 , the netters landed $178 \mathrm{t}$ of fish (77\% of the landings of the small-scale fishery in Vilanova).

During 2009, we interviewed the skippers of vessels that use nets. The interview survey consisted in contacting the owner-operator (who in all cases was the skipper) through the secretary of the Fishermen's Association and enquiring about their availability to respond to a socio-economic interview lasting approximately $1 \mathrm{~h}$. Fourteen out of the 21 skippers agreed to participate in the interview. The aim of the interviews was to compile information on the seasonality of the main target species, the characteristics of the fishing gear, and the economic parameters of the activity (Table 2 ). 


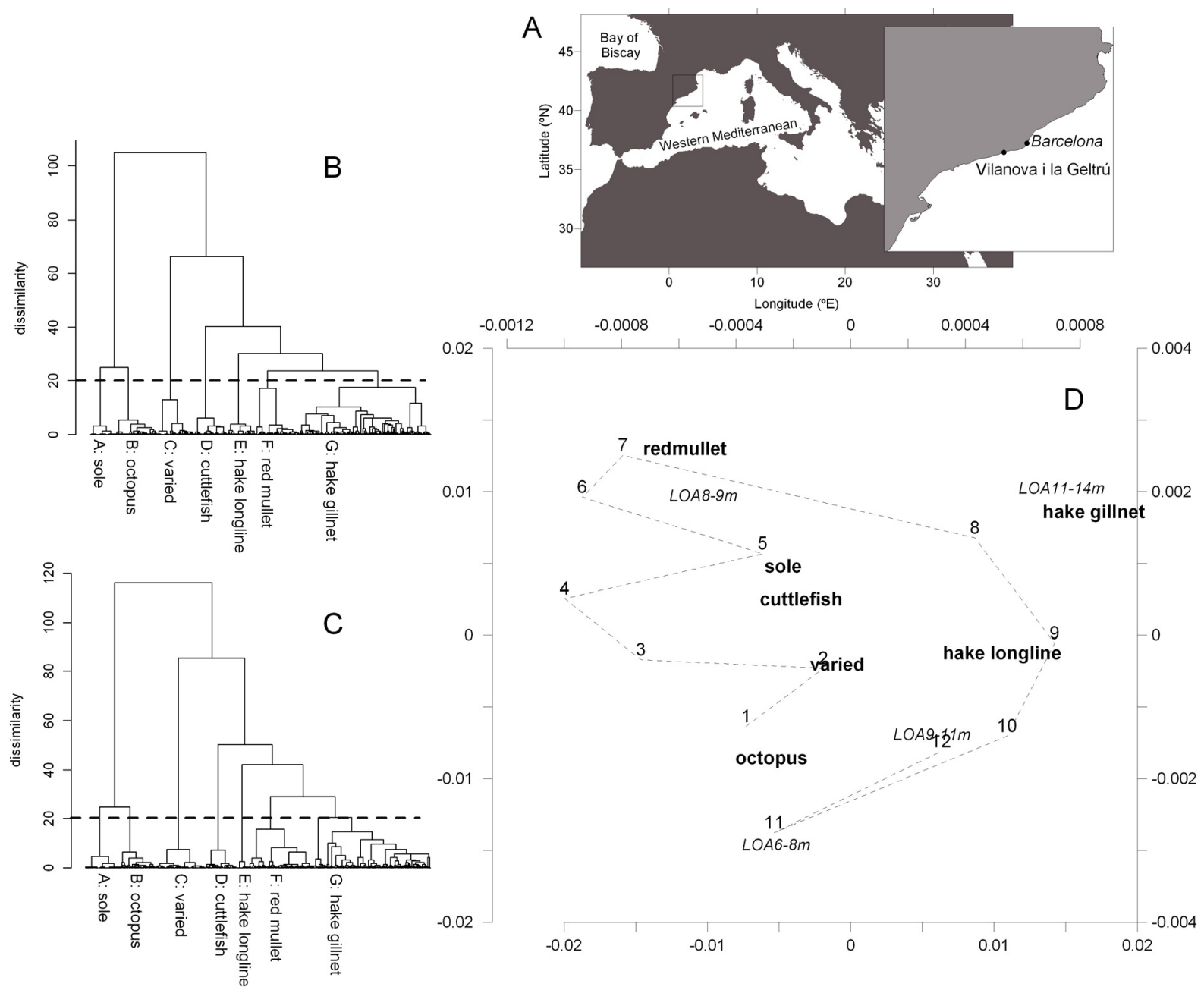

Fig. 1. A. Location of the study fishing harbour (Vilanova i la Geltrú), B: dendrogram of the cluster classification of fishing trips in terms of \% catch in volume, C: dendrogram of the cluster classification of fishing trips in terms of \% catch in value, D: Representation of the results of the multiple correspondence analysis (MCA) relating the 7 fishing tactics (in bold) established for the small-scale netter fleet of Vilanova to months of the year (1-12) and vessel groups (italics).

Table 1. Technical characteristics of the small-scale fishing fleet in Vilanova i la Geltrú in 2009. LOA: Length Overall, HP: Horse Power, GRT: Gross Register Tonnage

\begin{tabular}{lllll}
\hline & $\begin{array}{l}\text { Number } \\
\text { of boats }\end{array}$ & $\begin{array}{l}\text { Mean LOA } \\
(90 \% \text { quantiles })\end{array}$ & $\begin{array}{l}\text { Mean HP } \\
(90 \% \text { quantiles })\end{array}$ & $\begin{array}{l}\text { Mean GRT } \\
\text { (90\% quantiles) }\end{array}$ \\
\hline $\begin{array}{l}\text { Entire small-scale } \\
\text { fleet }\end{array}$ & 53 & $8.75(6.0-11.8)$ & $55.12(25.6-98.8)$ & $5.23(2.1-8.9)$ \\
Netters & 21 & $9.82(7.8-12.8)$ & $68.10(29.2-123.5)$ & $6.50(3.4-12.1)$ \\
\hline
\end{tabular}

\subsection{Multivariate analysis}

We followed a multivariate approach similar to that of Pelletier and Ferraris (2000) to determine the fishing tactics of the netters fleet segment, using both the catch volumes $(\mathrm{kg})$ and the catch values $(€)$. As the catch may vary greatly from one fishing trip to another, both in terms of species composition and quantity, we aggregated the catch of each species by boat on a monthly scale. The original data set was thus transformed into two matrices with rows denoting month $\times$ boat and columns denoting species. The contents of the first matrix was catch in $\mathrm{kg}$ and the contents of the second matrix was value of catch in euros. The data matrix was then transformed to the percentage species composition of each month $\times$ boat combination, to produce the monthly catch profile in terms of $\mathrm{kg}$ or value. The list of species retained was a subset of 53 species (or commercial categories) making up $>0.1 \%$ of the catch in the 10 -year period, and which comprised $99.1 \%$ of the entire catch in $\mathrm{kg}$ of this fleet segment in the study period $(98.5 \%$ in terms of value).

The next step in the multivariate analysis was to apply principal component analysis (PCA) to the percentage data 
Table 2. Summary of the socio-economic interview form.

\begin{tabular}{|c|c|c|}
\hline \\
\hline \multicolumn{3}{|l|}{$\begin{array}{l}\text { Boat identifier } \\
\mathrm{N}^{\circ} \text { of crew (incl. skipper) }\end{array}$} \\
\hline Name of fishing gear used & $\begin{array}{l}\text { Months of the year when used; } \\
\text { rigging and fitting }\end{array}$ & \\
\hline \multicolumn{3}{|l|}{$\begin{array}{l}\text { Cost structure (\% common costs; } \\
\% \text { share to the owner; } \\
\% \text { share to the crew) }\end{array}$} \\
\hline Annual fixed costs by category & $\begin{array}{l}\text { - dry dock (routine maintenance and } \\
\text { minor repairs; technical and safety } \\
\text { inspections) } \\
\text { - fishing gear (repair and purchase) } \\
\text { - taxes; insurance, mooring }\end{array}$ & \\
\hline Annual variable costs by category & $\begin{array}{l}\text { ice and bait } \\
\text { fuel } \\
\text { motor lubricant }\end{array}$ & \\
\hline Distribution of catch & $\begin{array}{l}\text { fish auction } \\
\text { direct sale } \\
\text { own consumption }\end{array}$ & \\
\hline In the last 5 years your catches have: & $\begin{array}{l}\text { increased } \\
\text { remained stable } \\
\text { decreased }\end{array}$ & \\
\hline $\begin{array}{l}\text { Your relationship with other users } \\
\text { of the coastal space can be } \\
\text { described as: }\end{array}$ & $\begin{array}{l}\text { Good cooperation } \\
\text { Conflictive } \\
\text { No contact }\end{array}$ & $\begin{array}{l}\text { Other users were listed as: } \\
\text { - small-scale fishers } \\
\text { - other fishers } \\
\text { - recreational fishers (boat) } \\
\text { - recreational fishers } \\
\text { (underwater speargun) } \\
\text { - sport divers } \\
\text { - jet ski } \\
\text { - wind surfers }\end{array}$ \\
\hline
\end{tabular}

matrix (Biseau and Gondeaux 1988). All the factorial axes were retained and the PCA scores (or factorial coordinates) were classified with hierarchical cluster analysis (HCA, using Euclidean distance and Ward's aggregation method, Pelletier and Ferraris 2000). Based on our experience with this fishery and the results of the socio-economic interviews, we chose a dissimilarity level of $20 \%$ as the cut off value. This resulted in 7 groups, both in the analysis based on catch volume and the analysis based on catch value (Figs. 1B, 1C) (as the results of the two analyses were very similar, only the results for the ordination based on the landings value are shown henceforth). These groups, or clusters of monthly fishing tactics by boat, were then related to the month of the year and the technical characteristics of the boat by means of multiple correspondence analysis (MCA, Pelletier and Ferraris 2000). The technical characteristics of the boats were summarized by the indicator length overall (LOA, m), because all three technical variables (LOA, engine power and gross register tonnage) were highly correlated. All analyses were carried out with the R 2.10 programming language, using the stats library (R Core Development Team 2010).

\section{Results}

The multivariate analysis showed that the small-scale netters of the Vilanova fleet practice 7 main fishing tactics
(Table 3 and Fig. 1D): sole, octopus, varied, cuttlefish hakelongline, redmullet and hake-gillnet. The ordination diagram shows the seasonal evolution (months 1-12) of the fishery, with the main fishing tactics practiced and the vessels arranged according to length classes (Fig. 1D). This figure shows that as the season progresses (reading along the second axis), the tactics change sequentially: the cuttlefish, sole and red mullet tactics are mainly carried out during spring and summer. In late summer and autumn the hake fishing tactics become more important, while the octopus tactic is practiced mainly in autumn and early winter. The fishing tactic that is practiced all year round (varied) appears close to the centre of the diagram, and is associated with the month of February, which is a transition period between the autumn and spring fishing tactics. Figure 1D also shows that the hake-gillnet tactic is practiced by the larger boats (LOA 11-14 m), while the smaller boats (LOA 6-8 m) tend to practice the octopus fishing tactic.

Each tactic is well defined by one single target species (which is usually used as the vernacular name of the fishing gear, as revealed by the interviews with the fishermen), except for tactic C varied (Table 3). Tactics A (sole), D (cuttlefish) and $\mathrm{F}$ (red mullet) are carried out with trammel nets of different mesh sizes and deployed at different times during the year (Fig. 2). Tactics E and G target hake (Merluccius merluccius) but with different fishing gears: bottom set longlines in the first case and gillnets in the second. Tactic B catches mainly octopus (Octopus vulgaris) using traps made of clay pots; however, 
Table 3. Definition of the 7 fishing tactics or métiers practiced by the small-scale netter fleet of Vilanova (21 vessels). Fishing tactics A to G are named informally after the main target species. Secondary species accounting for $5 \%$ or more of the catch are shown. The first value in brackets in the second column represents the percentage contribution to catches in weight; the second value is the percentage contribution to catches in value.

\begin{tabular}{|c|c|c|c|c|c|}
\hline Fishing tactic & Main species & Other species & $\begin{array}{l}\text { Fishing gear, } \\
\text { local name } \\
(\mathrm{FAO} \text { code }) \\
\left(\mathrm{DCF}^{\mathrm{a}}\right)\end{array}$ & $\begin{array}{l}\text { percentage } \\
\text { of vessels } \\
\text { practicing this } \\
\text { fishing tactic }\end{array}$ & $\begin{array}{l}\text { Number of } \\
\text { days at sea } \\
\text { in } 2008 \\
\text { (21 vessels) }\end{array}$ \\
\hline $\mathrm{A}-$ sole & $\begin{array}{l}\text { Solea vulgaris } \\
\text { and Solea } \\
\text { senegalensis } \\
(55 \%)(70 \%)\end{array}$ & $\begin{array}{l}\text { Lithognathus } \\
\text { mormyrus, } \\
\text { Octopus vulgaris, } \\
\text { Sepia officinalis } \\
\text { (5-10\% each) }\end{array}$ & $\begin{array}{l}\text { Sole trammel net, } \\
\text { "tresmall } \\
\text { de llenguado" } \\
(07.5 .0)(\mathrm{GTR})\end{array}$ & $82 \%$ & 120 \\
\hline B - octopus & $\begin{array}{l}\text { Octopus } \\
\text { vulgaris }(68 \%) \\
(90.3 \%)\end{array}$ & $\begin{array}{l}\text { Solea spp. (5\%) } \\
(1 \%)\end{array}$ & $\begin{array}{l}\text { Clay pots, } \\
\text { "Cadups" } \\
(08.2 .0)(\mathrm{FPO})\end{array}$ & $73 \%$ & 50 \\
\hline $\mathrm{C}$ - varied & & $\begin{array}{l}\text { Lithognathus } \\
\text { mormyrus }(8.2 \%) \\
(8 \%), \\
\text { Seriola } \\
\text { dumerilii }(7.6 \%) \\
(7 \%), \\
\text { mixed fishes } \\
(7.6 \%)(7.1 \%)\end{array}$ & $\begin{array}{l}\text { striped seabream } \\
\text { gillnet, } \\
\text { "solta de mabre" } \\
(07.9 .1)(\mathrm{GNS})\end{array}$ & $100 \%$ & 520 \\
\hline D - cuttlefish & $\begin{array}{l}\text { Sepia officinalis } \\
(26.2 \%) \\
(26.3 \%)\end{array}$ & $\begin{array}{l}\text { Bolinus } \\
\text { brandaris }(19 \%) \\
(4 \%), \text { Solea spp. } \\
(12 \%)(17 \%)\end{array}$ & $\begin{array}{l}\text { Cuttlefish } \\
\text { trammel net, } \\
\text { "tresmall de sípia" } \\
(07.5 .0) \text { (GTR) }\end{array}$ & $100 \%$ & 150 \\
\hline $\mathrm{E}$ - hake - longline & $\begin{array}{l}\text { Merluccius } \\
\text { merluccius } \\
(44 \%)(40.8 \%)\end{array}$ & & $\begin{array}{l}\text { bottom set } \\
\text { longline } \\
\text { "palangre a penjar" } \\
(09.3 .0)(\text { LLS) }\end{array}$ & $64 \%$ & 100 \\
\hline $\mathrm{F}$ - redmullet & $\begin{array}{l}\text { Mullus } \\
\text { surmuletus } \\
(41 \%)(58.2 \%)\end{array}$ & $\begin{array}{l}\text { Scorpaena spp. } \\
(15 \%)(8.7 \%)\end{array}$ & $\begin{array}{l}\text { Striped red } \\
\text { mullet trammel net, } \\
\text { "tresmall de moll" } \\
(07.5 .0)(\mathrm{GTR})\end{array}$ & $36 \%$ & 80 \\
\hline $\mathrm{G}$ - hake - gillnet & $\begin{array}{l}\text { Merluccius } \\
\text { merluccius } \\
(84 \%)(81.6 \%)\end{array}$ & & $\begin{array}{l}\text { Merluccius } \\
\text { gillnet, } \\
\text { "solta de lluç" } \\
(07.9 .1)(\mathrm{GNS})\end{array}$ & $46 \%$ & 60 \\
\hline
\end{tabular}

${ }^{\text {a }}$ FAO code followed by the code used for Mediterranean fishing gear in the fisheries Data Collection Framework (DCF) of the European Commission.

as sole is frequently caught in this fishing tactic ( $5 \%$ in volume, $1 \%$ in value, Table 3 ) it is probable that a trammel net is used at the same time. Finally, although tactic $\mathrm{C}$ has a very varied catch composition, the most frequent species caught was the striped seabream (Lithognathus mormyrus), which lends its name to the trammel net used in this tactic.

The evolution of the average value per unit effort (VPUE: $€ /$ month/boat, Fig. 2) is shown, and average monthly number of trips for each fishing tactic. The seasonality in effort (number of trips) is not always in good agreement with the seasonality in VPUE; for instance, while the VPUE and number of trips vary synchronously in tactics B, D and F, the VPUE of sole (tactic A) and hake (tactic G) are higher in late spring and summer, before the peak in fishing effort. Tactics $\mathrm{C}$ and $\mathrm{E}$ show relatively low seasonality, although higher VPUE is generally observed in summer (Fig. 2).
It is apparent that only tactic B shows a strong decrease in the interannual evolution of fishing effort (average number of trips, Fig. 3) from 2000 to 2009. The progressive disappearance of tactic B, and the simultaneous decrease in VPUE is not only due to a possible reduction in the abundance of Octopus vulgaris, but probably to the limited productivity of this traditional fishing gear. Landings data in Vilanova show that the total landings of $O$. vulgaris by other fleets (mainly trawl) in this port decreased from $256 \mathrm{t}$ in 2000 to $77 \mathrm{t}$ in 2009 (unpubl. data), and tactic B never accounted for more than $16 \%$ of this production (Fig. 4). The VPUE of cuttlefish, the target species of tactic D, has more than doubled. The VPUE of hake and red mullet varied without a clear trend between 2000 and 2009 (Fig. 3).

The series of catches and ex-vessel prices are shown for the target species in each tactic (Fig. 4). Considering that 

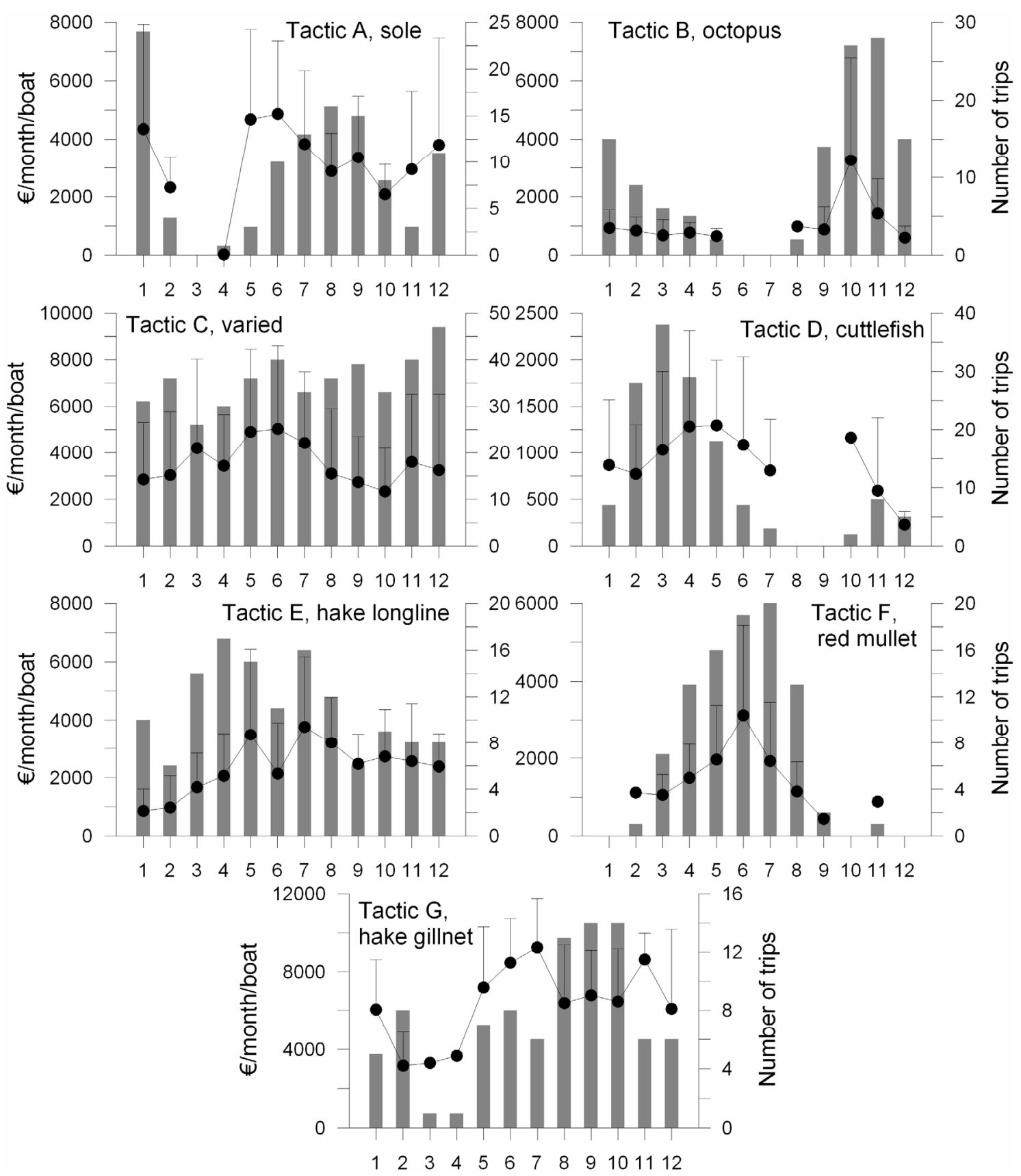

Fig. 2. Monthly evolution of the tactics identified for the small-scale netter fleet of Vilanova. Lines with filled circles correspond to the average VPUE ( $€ /$ month/boat, nominal) of each target species of each fishing tactic with 1 standard deviation. Bars correspond to the average monthly number of trips conducted by the fleet for each fishing tactic.

the production of the small-scale netter fleet in Vilanova is low compared with the production of other fleets in the same port or important neighbouring ports such as Barcelona or Tarragona, we can assume that local prices are not dictated by local offer, but rather imposed on the fishers (i.e. netters in Vilanova are price-takers). The annual production of each fishing tactic is more clearly related to the effort deployed (cf. landings value in Fig. 4 with number of trips in Fig. 3) than to the target species price. Although intuitively it would seem that the amount of effort would be related to the price offered in the market, this is not clear when data on prices
(Fig. 4) and effort (Fig. 3) are compared. Pairwise correlation between annual catch and average monthly number of trips ranged between 0.75 and $0.95(p<0.05)$ for all fishing tactics, except $\mathrm{C}$ (varied). However, fish production was not significantly correlated with prices, except for fishing tactic B (octopus), for which the correlation was even negative $(r=-0.73, p=0.016)$. This suggests that fishers have certain control over the production of each species by deciding the amount of effort devoted to a specific fishing tactic.

Figure 4 (lower right panel) also shows that the total income of the netters fleet varied from year to year between 

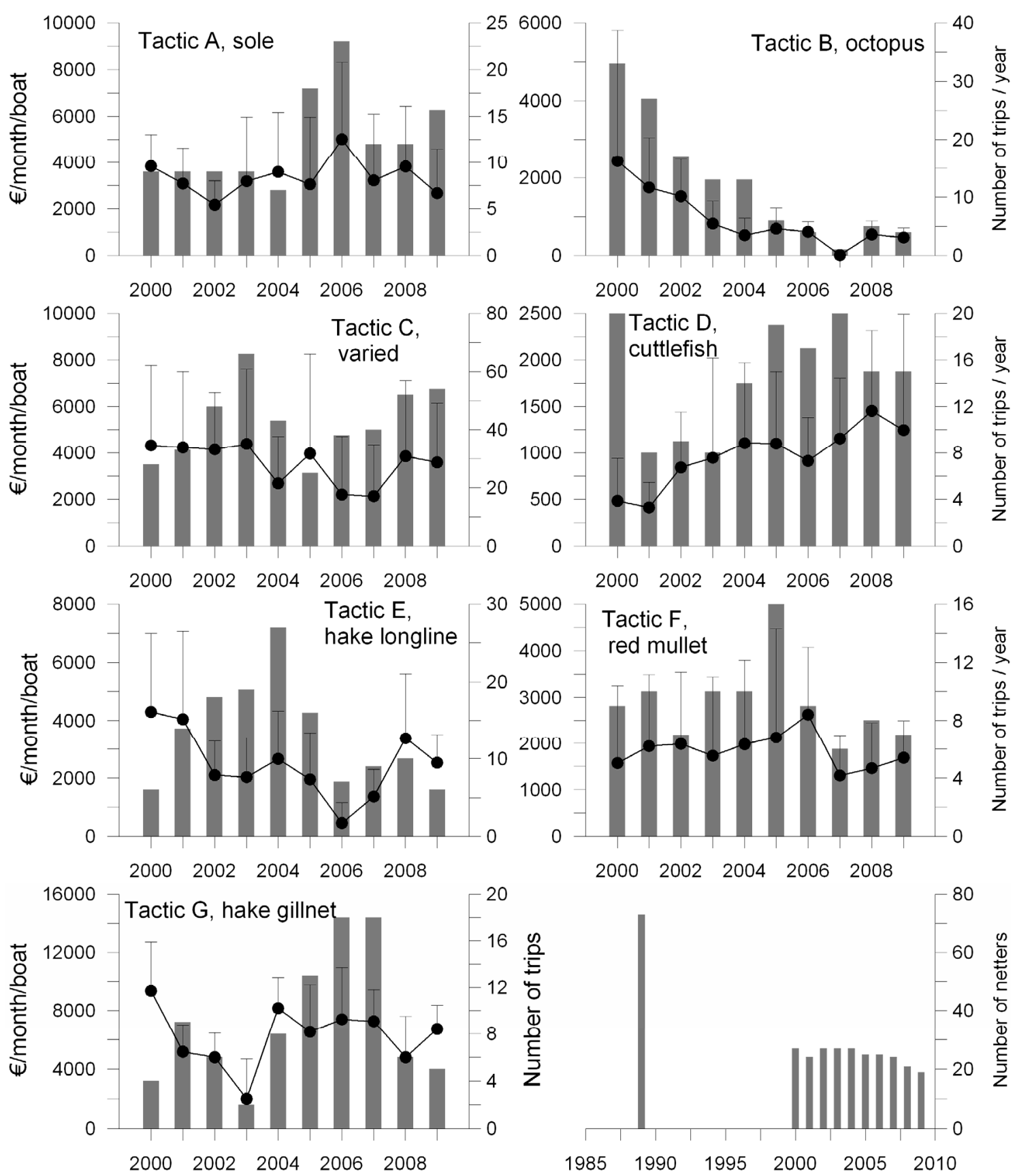

Fig. 3. Interannual evolution of the tactics identified for the small-scale netter fleet of Vilanova. Lines with filled circles represent the average monthly mean VPUE (€/month/boat, nominal) in that year for each target species of each fishing tactic, with 1 standard deviation. Bars represent the average monthly number of fishing trips for each fishing tactic. Lower right chart: evolution of the units in the small-scale netters fleet over the last 20 years.

350 and 550 thousand euros with no trend, while the total production of target species decreased from $\mathrm{ca}$. $100 \mathrm{t}$ in 2000 to $c a$. $60 \mathrm{t}$ in 2009. This difference is due to the practical disappearance of tactic $\mathrm{B}$, since the production of the other tactics over the same period has fluctuated without trend.

The analysis of the fishermen's responses to the economic questions in the interviews (14 boat owners out of 21 agreed to participate in the survey) allowed us to gain an idea of the financial situation of the netters (Table 4). The capital invested in the activity (as deduced from the declared sale value) is on average 138 thousand euros per vessel. All vessels carried 1 or 2 people, and the owner-operator was always the skipper. Total costs averaged around 43 thousand euros, $71 \%$ of which was due to variable costs (mainly ice, bait and fuel). The share to the owner, which should in theory be considered a wage and make up a significant part of the variable costs $(74 \%)$, was actually pooled with the profits of the enterprise because the skipper is always the owner in small-scale Mediterranean 

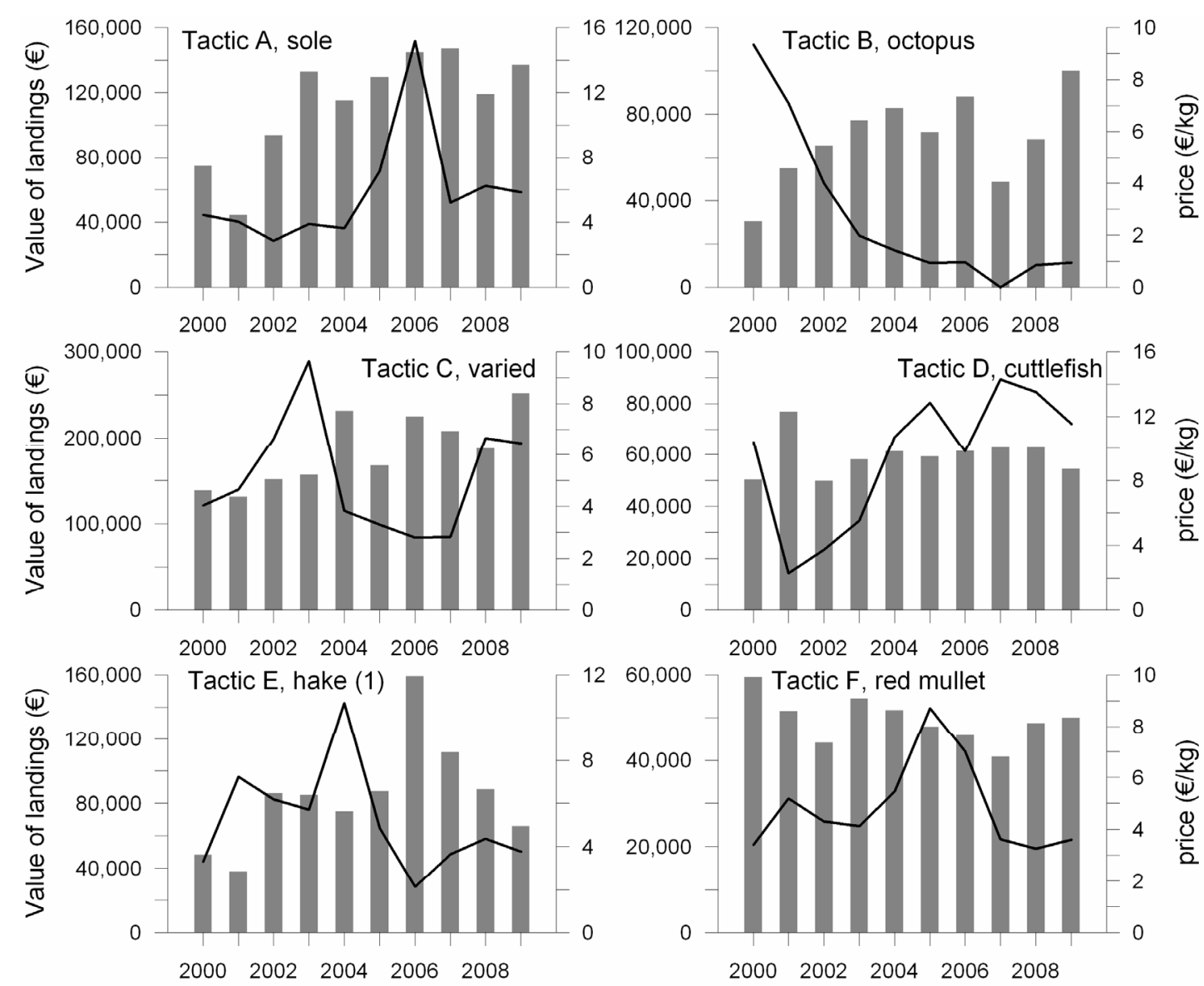

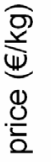

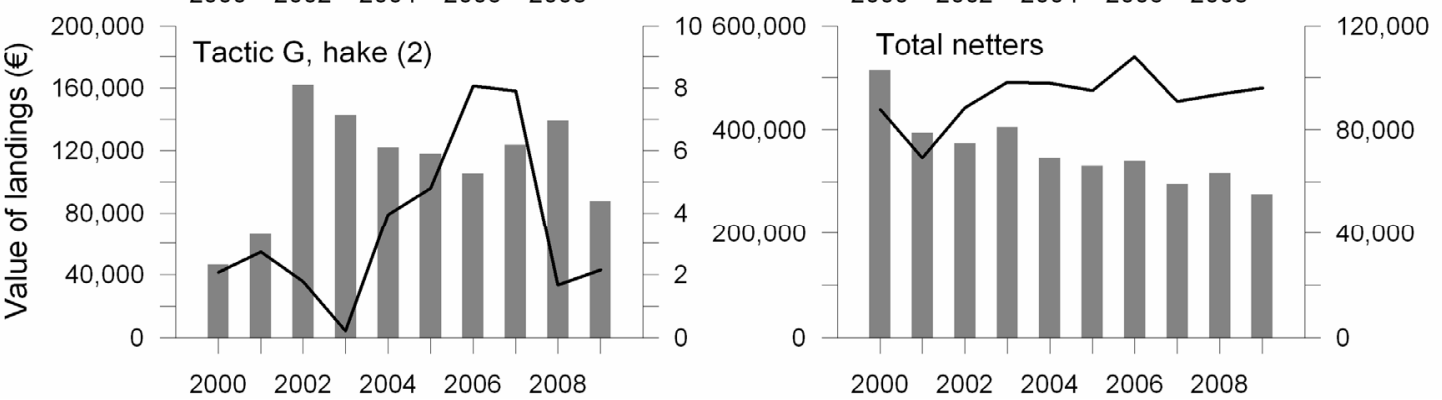

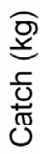

Fig. 4. Landings values of the tactics identified for the small-scale netter fleet of Vilanova. Lines represent the total annual catch in value (€, nominal) for each target species of each fishing tactic. Bars represent the average price of the target species for each fishing tactic (€/kg, nominal), except for the lower right chart where bars are annual catches.

fisheries. The crew wage, $16636 € /$ year, was more than double the official monthly minimum salary in Spain in 2008 (600 €/month). Gross surplus and net profits (after discounting the opportunity cost) were relatively high, $c a .20$ and 16 thousand euros/year respectively, with a return on investment of $11.57 \%$. The net income of the owner-operator was $38584 €$. However, these average figures mask the fact that $35 \%$ of the vessels had losses in 2008 (which would be $43 \%$ if we take into account the opportunity cost).

The information on the value of landings reported by fishers was cross-checked with the information available in the 2008 production statistics and was generally consistent. The average value of landings declared in the interviews was $54077 € /$ vessel in 2008, compared with the $63048 € /$ vessel estimated from the statistics for the same year (14\% lower). The maximum difference between the value of landings reported in the interviews and the value of landings calculated from the statistics was $30 \%$ in one case, but in most cases the difference was between 5 and $10 \%$. The difference can be attributed to inexact memory, rather than an attempt to mislead the interviewer, because some fishers reported higher landings values and others reported to have fished less than shown in the statistics. The landings values from the production statistics were used in the economic analysis (Table 4).

The answers to questions on the state of the resources and conflicts with other users showed that 13 out of the 14 interviewees considered that the fish catches have decreased in recent years (the remaining fisher believed that catches have 
Table 4. Economic parameters from the interviews of fishers from the Vilanova fleet. Values reported are averages for vessels of the small-scale netter segment. $N=14$ respondents; survey carried out during 2009; questions refer to 2008. Total value of catch and volume obtained from landings statistics.

\begin{tabular}{llll}
\hline & Mean per vessel & $10 \%$ and $90 \%$ quantiles & Comment \\
\hline Capital (boat value, $€$ ) & 137714 & $60000-231000$ & \\
Crew size & 1.71 & $1-2$ & \\
Average number of days at sea & 120 & $35-180$ & \\
Total costs $(€)$ & 42989 & $15050-66688$ & $28.95 \%$ of total costs \\
Fixed costs $(€)^{\mathrm{a}}$ & 12445 & $7904-19546$ & $71.05 \%$ of total costs \\
Variable costs $(€)$ & 30544 & $2540-48167$ & \\
Owner-operator wage $(€)$ & 22656 & $15000-35000$ & only calculated for vessels with 2 crew members \\
Crew wage $(€)$ & 16636 & $11940-21668$ & \\
Fuel cost $(€)$ & 5561 & $1843-12760$ & \\
Value of catch 2008 $(€)$ & 63048 & $34904-90461$ & \\
Volume of catch 2008 $(\mathrm{kg})$ & 8107 & $4517-14143$ & \\
& & & \\
Gross surplus $(€)$ & 20059 & & \\
Opportunity costs $\left(3 \%\right.$ of capital) ${ }^{\mathrm{b}}$ & 4131 & & \\
Net profit $(€)$ & 15928 & & \\
Return on investment $($ RoI $)$ & $11.57 \%$ & & \\
Net income of the owner-operator & 38584 & & \\
\hline
\end{tabular}

a including capital depreciation costs, estimated at $3900 €$ for a useful life of 30 years.

${ }^{b}$ Interest rate of the European Central Bank for 2007 (source: Eurostat)

remained the same). Between 60 and $70 \%$ of the fishers agreed that there are conflicts around the use of resources with other fleet segments and with recreational fishers, while none reported conflicts with other types of recreational users (nonextractive uses).

\section{Discussion}

The small-scale fishing fleet analyzed here (Table 1) has similar technical characteristics to other small-scale fisheries in the Mediterranean. For instance, Forcada et al. (2010) and Tzanatos et al. (2006) report very similar values of overall length, gross registered tonnage and engine power in the Gulf of Alicante (Spain) and the Gulf of Patraikos (Greece).

Our results show that the small-scale coastal net fishery in Vilanova practiced 7 clearly defined fishing tactics in the period 2000-2009. The fishing tactics mainly correspond to different types of trammel nets (in terms of mesh size only), with the use of gillnets, longlines and clay pots for specific target species (hake in the case of gillnets and longlines, and octopus in the case of clay pots). Most fishing tactics are used at specific times of the year, with a seasonal rotation dictated by the availability of the target species (e.g. cuttlefish in late winter and spring, red mullet in late spring and summer, sole in spring and summer, and octopus in autumn). The vessels in the fleet segment typified as "small-scale" in terms of their license, generally practice all of the various fishing tactics that are traditional in the area, although the gillnet fishing tactic, which is practiced farther from the harbour, tended to be carried out by larger vessels. The octopus fishing tactic practically disappeared during the study period, as previously described by Lleonart (1990). This fishing tactic was well-documented along the Spanish Mediterranean coast
(Lleonart 1990; Sánchez and Obarti 1993) in the 1980s and 1990 s, but it seems to be currently disappearing. Information on long-term changes in the use of fishing gears in small-scale fisheries is very scarce and specific studies are necessary. For instance, Forcada et al. (2010) documented the introduction of the Merluccius gillnet (corresponding to our fishing tactic hake-gillnet) in the area of the Gulf of Alicante in 1995, and its widespread use by the larger vessels afterwards; however, in 2003-2005 it had practically disappeared.

Tzanatos et al. (2006) reported that two important fishing tactics present in the Gulf of Patraikos (Greece, one targeting Penaeus kerathurus in spring-early summer and the other targeting Sepia officinalis in autumn-winter) were also present in the Gulf of Gabès (Tunisia; Jabeur et al. 2000) and raised the question of whether these two fishing tactics are present throughout the Mediterranean. The answer is affirmative at least for the $S$. officinalis fishing tactic because it has been identified in several areas of the Spanish coast (Forcada et al. 2010; García-Rodríguez et al. 2006; Merino et al. 2008) as well as in the present study. In fact, 5 of our 7 fishing tactics (cuttlefish, sole, redmullet, hake-longline and hake-gillnet) are well represented in other Mediterranean small-scale fisheries in terms of target species and seasonality, although the rigging of the fishing gear may differ slightly. For instance the cuttlefish and red mullet fishing tactics, with similar species compositions and seasonality as in our study, are present in numerous other Mediterranean areas: in the Cilento (southern Italy) artisanal fishery (Colloca et al. 2004: Table 3); in the Balearic Islands trammel net fishery (Merino et al. 2008); in the Cyclades spring-summer red mullet trammel net fishery (Stergiou et al. 2006); and in the Alicante Gulf small-scale fishery (Forcada et al. 2010). Likewise, our fishing tactic hake-longline, which uses bottom set longlines to fish for M. merluccius, is similar to tactic L2 in the Gulf of 
Patraikos (Tzanatos et al. 2006: Table 1), and our fishing tactic hake-gillnet, which uses a Merluccius gillnet was also documented by García-Rodríguez et al. (2006) in the Alicante Gulf.

Fishing tactics simultaneously reflect the decision of the fisher (target species, gear and location at specific times of the year) and the results of that decision: the catch composition. The typology of fishing tactics provides a synthetic representation of the fishing operations, which is a necessary step for understanding the dynamics of mixed fisheries. The fleet is thus partitioned into components that have similar impacts on the resources, which helps design management measures that target particular fishing activities. Species directed effort and abundance indices can be calculated for each tactic and used in assessment methods. Identifying common fishing tactics in Mediterranean small-scale fisheries of different countries facilitates monitoring and managing them, and contrasts with the widespread notion of highly variable and difficult to typify fisheries. For instance, García-Rodríguez et al. (2006) found that small-scale fisheries are sustained by a few species (or species groups) and that the 3 main gear types produce $82 \%$ of the landings. From the assessment and management points of view, it is important to note that there are some fishing tactics that are relatively "clean", with a clear target species that comprises most of the catch of the fishing trip and relatively low bycatch (or discards), such as our hake-gillnet tactic, for which $84 \%$ of the catch was constituted by the main species (Merluccius merluccius). The target species made up more than $40 \%$ of the catch composition in 4 other tactics, while only 2 tactics were much less selective and included a large number of bycatch species (varied and cuttlefish).

Fishers rotate métiers throughout the year to optimize yields (Forcada et al. 2010), targeting specific stages in the life histories of commercial species, such as spawning, nursery or wintering grounds (Stergiou et al. 2006; Tzanatos et al. 2006). This clear temporal and spatial definition of the activity may help manage small-scale fisheries according to the use they make of the space over time; however, we agree with Tzanatos et al. (2006) that small-scale fishers are able to get around restrictive management actions due to their flexibility in switching métiers, and therefore these actions may result in excess fishing effort on other species or habitats.

Fishers allocate fishing effort in a given area in a given season not only based on prior information on costs and the expected benefits (Hilborn and Ledbetter 1979; Sampson 1991), but also based on tradition and (in some places) spatial restrictions of the fishing effort (Pelletier and Ferraris 2000). In our case study, we found a good relationship between the volume of catches and the number of trips (or fishing effort), which suggests that small-scale fishers may control the quantity of landings to some extent by modulating fishing effort.

The catch of small-scale coastal fishers has decreased in general over the period 2000-2009. In Catalonia this fleet segment landed $3840 \mathrm{t}$ in 2000 and only $2480 \mathrm{t}$ in 2009. In our case study port (Vilanova) the reduction is even clearer: landings decreased from $482 \mathrm{t}$ to $230 \mathrm{t}$, which represents a reduction of more than $50 \%$. This is in good agreement with the perception of fishers, $93 \%$ of whom declared a reduction in catches in recent years. The general decrease in catches means that small-scale fisheries now make very little profit, which has led in turn to a reduction in fleet size (the number of netters in 1989 in Vilanova was 73: Lleonart 1990). Despite the economic results reported in Table 4 , which show a relatively positive situation for 2008 , we must note than $1 / 3$ of the vessels had financial losses and only $1 / 4$ of the vessels had profits higher than the average (from 20 to 42 thousand euros). This may result in further reductions of the fleet in the future as skippers (or owner-operators) retire and no young people become interested in the fishery, which was reported by the fishers themselves.

The return on investment (around 12\%) is consistent with other estimates for small-scale fleets in European fisheries (Boncoeur et al. 2000), which suggests that these fisheries are profitable and would attract investment (internal or external). However, the same authors caution against using the return of investment indicator based on its classic definition (full equity profits/value of capital) for small-scale fleets and suggest using an alternative indicator, such as net income to the owneroperator. This indicator resulted in $38 \mathrm{k} €$ in our fleet, which is in the lower range of the English Channel fleets studied by Boncoeur et al. (2000), and in the range of average salaries (before tax) in Spain in 2008, which suggests that this activity would not attract new entrants or new investments.

The lack of economic prospects in coastal fisheries for would-be fishers, combined with the state of the marine living resources and the conflicts with other users (especially extractive users) suggest a bleak future for small-scale fisheries in the study area, which can be extrapolated to other European smallscale fisheries (Guyader 2007). For instance, Gómez et al. (2006) concluded that the decline in artisanal fisheries in the Cape Creus area (northern Catalonia) was due to a combination of sociocultural, economic and environmental causes and not even the establishment of a marine reserve in 1998 could stem the observed decline. These authors believed the solution to be integrated coastal management plans. Only management actions that reduce the fishing pressure on coastal resources but at the same time make it economically viable to remain in the activity will stop the decline of coastal fisheries communities. Diversifying work opportunities for fishers is a promising way of successfully solving the problem (Alban and Boncoeur 2005; Colloca et al. 2004).

Guyader (2007) concluded that the main threat to smallscale coastal fisheries in Europe was large-scale fisheries, with recreational fishers as the second most important competitor for resources and space. It is urgently necessary to address this competition with large-scale fisheries. Small-scale fisheries need to be promoted because they have a lower impact on the resources and environment as well as provide a better quality product (for instance, in terms of freshness) (Guyader 2007; Merino et al. 2008). These aspects could be used by fisheries managers to the advantage of small-scale fisheries by promoting their product in terms of "eco-labelling" and "environmentally friendly" sea products. The advantages of smallscale fisheries are that they are highly selective, generate few discards, have a low impact on sea bottoms and diversify employment opportunities in coastal zones. Garcia et al. (2008) highlighted the need to develop conventional fisheries management into an integrated assessment and advisory framework specific to small-scale fisheries. 
Acknowledgements. We thank the General Fisheries Directorate of the Autonomous Government of Catalonia for access to the fish auction database and the Fishermen's Association of Vilanova i la Geltrú for their cooperation during the field sampling. We thank Marta Cavallé and Cristina López for assistance during field sampling. Field work was partly funded by the "Conflict" project (Ref. CGL2008-00047 of the Spanish National Research Plan. The opinions of two anonymous reviewers helped improve the quality of the manuscript.

\section{References}

Alarcón J.A., 2001, Inventario de la Pesca Artesanal en España Mediterránea (2000-2001). FAO-COPEMED, mimeo. http://www.faocopemed.org/old_copemed/vldocs/0000562/ artfi_sp.pdf

Alban F., Boncoeur J., 2005, Pêche professionnelle, pêche récréative et tourisme : examen des potentialités de développement d'une pluriactivité en mer d'Iroise. Les publications AMURE. Série document de travail. $\mathrm{N}^{\circ}$ D-08-2008. ISSN 1951-641X.

Alió J.J., Marcano L., Soomai S., Phillips T., Altuve D., Alvarez R., Die D., Cochrane K., 2000, Analysis of industrial trawl and artisanal fisheries of whitemouth croaker (Micropogonias furnieri) of Venezuela and Trinidad and Tobago in the Gulf of Paria and Orinoco River Delta. FAO Fish. Rep. 628, 138-148.

Biseau A., Gondeaux E., 1988, Apport des méthodes d'ordination en typologie des flottilles. J. Cons. Int. Explor. Mer 44, 286-296.

Boncoeur J., Coglan L., Le Gallic B., Pascoe S., 2000, On the (ir)relevance of rates of return measures of economic performance to small boats. Fish. Res. 49, 105-115.

Colloca F., Crespi V., Cerasi S., Coppola S.R., 2004, Structure and evolution of the artisanal fishery in a southern Italian coastal area. Fish. Res. 69, 359-369.

COM, 2002, 535 final, Communication from the Commission to the Council and the European Parliament laying down a Community Action Plan for the conservation and sustainable exploitation of fishery resources in the Mediterranean Sea under the Common Fisheries. Commission of the European Communities, Brussels, $37 \mathrm{p}$.

Forcada A., Valle C., Sánchez-Lizaso J.L., Bayle-Sempere J.T., Corsi F., 2009, Structure and spatio-temporal dynamics of artisanal fisheries around a Mediterranean marine protected area. ICES J. Mar. Sci. 67, 191-203.

Garcia S.M., Allison E.H., Andrew N.J., Béné C., Bianchi G., de Graaf G.J., Kalikoski D., Mahon R., Orensanz J.M., 2008, Towards integrated assessment and advice in small-scale fisheries: principles and processes. FAO Fish. Aquac. Tech. Paper No. 515. Rome, FAO, 84 p.

García-Rodríguez M., Fernández A.M., Esteban A., 2006, Characterisation, analysis and catch rates of the small-scale fisheries of the Alicante Gulf (SE Spain) over a 10 years time series. Fish. Res. 77, 226-238.
Gómez S., Lloret J., Demestre M., Riera V., 2006, The decline of the artisanal fisheries in Mediterranean coastal areas: the case of Cap de Creus (Cape Creus). Coast. Manage. 34, 217-232.

Griffiths R.C., Robles R., Coppola S.R., Camiñas J.A., 2007, Is there a future for artisanal fisheries in the western Mediterranean? Rome, FAO-COPEMED.

Guyader O. (coord.), 2007, Small-scale coastal fisheries in Europe. Final Report of the project. European Commission FISH/2005/10.

He X., Bigelow K.A., Boggs C.H., 1997, Cluster analysis of longline sets and fishing strategies within the Hawaii-based fishery. Fish. Res. 31, 147-158.

Hilborn R., Ledbetter M., 1979, Analysis of the British Columbia salmon purse-seine fleet: dynamics of movement. Can. J. Fish. Aquat. Sci. 36, 384-391.

Jabeur C., Gobert B., Missaoui H., 2000, Typologie de la flottille de pêche cotière dans le golfe de Gabès (Tunisie). Aquat. Living Resour. 13, 421-428.

Laloë F., Samba A., 1991, A simulation model of artisanal fisheries of Senegal. ICES J. Mar. Sci. Symp. 193, 281-286.

Lleonart J. (coord.), 1990, La pesca en Cataluña y Valencia. Final Report of the project, European Commission DG XIV, Ref. 1989/3.

Lleonart J., 2008, Review of the state of Mediterranean and Black Sea fishery resources. In Basurco B. (ed.). The Mediterranean fisheries sector. Options Méditerranéennes, Ser. B, 62, 57-69.

Merino G., Morales-Nin B., Maynou F., Grau A.M., 2008, Assessment and bioeconomic analysis of the Majorca (NW Mediterranean) trammel net fishery. Aquat. Living Resour. 21, 99-107.

Pelletier D., Ferraris J., 2000, A multivariate approach for defining fishing tactics from commercial catch and effort data. Can. J. Fish. Aquat. Sci. 57, 51-65.

R Development Core Team, 2010, R: A language and environment for statistical computing. R Foundation for Statistical Computing, Vienna.

Salas S., Gaertner D., 2004, The behavioural dynamics of fishers: management implications. Fish Fish. 5, 153-167.

Sánchez P., Obarti R., 1993, The biology and fishery of Octopus vulgaris caught with clay pots on the Spanish Mediterranean coast. In: Okutani T., O’Dor R.K., Kubodera T. (eds.), Recent Advances in Fisheries Biology, Tokyo, Tokai University Press, pp. 477-487.

Stergiou K.I., Moutopoulos D.K., Soriguer M.C., Puente E., Lino P.G., Zabala C., Monteiro P., Errazkin L.U., Erzini K., 2006, Trammel net catch species composition, catch rates and métiers in southern European waters: A multivariate approach. Fish. Res. $79,170-182$.

Tzanatos E., Somarakis S., Tserpes G., Koutsikopoulos C., 2006, Identifying and classifying small-scale fisheries métiers in the Mediterranean: A case study in the Patraikos Gulf, Greece. Fish. Res. 81, 158-168. 